African Futures 


\section{African Futures}

\section{Essays on Crisis, Emergence, and Possibility Brian Goldstone and Juan Obarrio The University of Chicago Press \\ Chicago and London}

\{ ? IQ: Author bio to come from marketing.\}

The University of Chicago Press, Chicago 60637

The University of Chicago Press, Ltd., London

(C) 2016 by The University of Chicago

All rights reserved. Published 2016.

Printed in the United States of America

2524232221201918171612345

ISBN-13: 978-0-226-40224-6 (cloth)

ISBN-13: 978-0-226-40238-3 (e-book)

ISBN-13: 978-0-226-40241-3 (e-book)

DOI: 10.7208/chicago/9780226402413.001.0001

CIP data to come

$\{\sim ?$ TN: set infinity symbol in circle $\} \infty$ This paper meets the requirements of ANSI/NISO Z39.48-1992 (Permanence of Paper). 


\section{Contents}

Chapter 1: Introduction: Untimely Africa?

Brian Goldstone and Juan Obarrio

\section{Part I: Rethinking Crisis}

Chapter 2: Africa Otherwise

Janet Roitman

Chapter 3: The Form of Crisis and the Affect of Modernization

Brian Larkin

Chapter 4: The Productivity of Crisis: Aid and Medicine in Mozambique

Ramah McKay

\section{Part II: Emergent Economies}

Chapter 5: Money in the Future of Africans

Jane I. Guyer

Chapter 6: Forensics of Capital

Michael Ralph

Chapter 7: Brokering Revolution: Imagining Future War on the West African Borderlands Danny Hoffman

Chapter 8: Hedging the Future

Charles Piot

Chapter 9: Entangled Postcolonial Futures: Malagasy Marriage Migrants and Provincial

Frenchmen

Jennifer Cole

\section{Part III: Urban Spaces and Local Futures}

Chapter 10: Rough Towns: Mobilizing Uncertainty in Kinshasa

AbdouMaliq Simone

Chapter 11: Local Futures, the Future of the Local: Urban Living in a Central African Metropolis Filip De Boeck

Chapter 12: Changing Mobilities, Shifting Futures

Peter Geschiere and Antoine Socpa

Chapter 13: Time and Again: Locality as Future Anterior in Mozambique Juan Obarrio 


\section{Part IV: Possibilities}

Chapter 14: Getting Ahead When We're Behind: Time, Potential, and Value in Urban Tanzania Brad Weiss

Chapter 15: Africa in Theory

Achille Mbembe

References

Index 